\title{
Neonatal jaundice
}

\section{Neonatal jaundice}

\section{Definition}

yellow discoloration of the skin and the mucosa is caused by accumulation of excess of bilirubin in the tissue and plasma (serum bilirubin level should be in excess $7 \mathrm{mg} / \mathrm{dl} .30-50 \%$ of term newborn and more of preterm newborns develop clinical jaundice. ${ }^{1}$

\section{Types of jaundice}

\section{Physiological jaundice}

Jaundice usually appears on $2^{\text {nd }}$ and $3^{\text {rd }}$ day and disappears by $7^{\text {th }}$ $-10^{\text {th }}$ day.

\section{Pathological jaundice}

Jaundice appearing in the first 24 hours or greater than 14 days of life. Increases in the level of total bilirubin by more than $8.5 \mu \mathrm{mol} / 1$ $(0.5 \mathrm{mg} / \mathrm{dL})$ per hour or $(85 \mu \mathrm{mol} / 1) 5 \mathrm{mg} / \mathrm{dL}$ per 24 hours.

\section{Etiology}

i. Increased red cell volume and increased red cell destruction due to shorter life span ( 90 days compared to 120 days in adult) in the neonate.

ii. Increased enterohepatic circulation due to decreased gut motility.

iii. Decreased hepatic excretion of bilirubin.

iv. Excessive red cell haemolysis: hemolytic disease of the newborn-feto-maternal blood group incompatibilities.

v. Deficient red cell enzyme-glucose 6-phosphate dehydrogenase

vi. Sepsis: intrauterine (toxoplasma, rubella infection).

vii. Metabolic and endocrine disorders: galactosaemia-there is hereditary deficiency of an enzyme-galactose 1 phosphate uridyl transferase which leads to cirrhosis of liver.

viii. Increased enterohepatic circulation of unconjugated bilirubin, duodenal atresia, pyloric stenosis, less frequent feeding.

ix. Miscellaneous: congenital obstruction, asphyxia, polycythaemia, thalassaemia.

\section{Clinical manifestation}

Examination of baby should be done in natural day light the color of the nails, sclera, mucous membrane and skin including the palms and soles is observed. Jaundice can come on suddenly, but it often develops over a period of weeks. Symptoms of jaundice include. ${ }^{2}$

Skin that is turning yellow

1. Yellow in the whites of your eyes.

2. A yellow tint inside your mouth.

3. Dark urine.
Volume 2 Issue 5 - 2017

\section{Sanjay S Shinde, Firew T \\ Ministry of education Mizan Tepi University, Ethiopia}

Correspondence: Sanjay S.Shinde, Assistance Professor, Ministry of education Mizan Tepi University, Ethiopia, Email mscshinde@gmail.com

Received: October 19, 2016 | Published: April 06, 2017
4. Pale stools.

\section{Diagnostic evaluation}

\section{Diagnostic testing may include}

a. History collection, physical examination

b. Blood tests to determine bilirubin levels

c. Complete blood count

d. Liver function testing

e. Abdominal imaging tests such as a CT scan or ultrasound

f. Liver biopsy

\section{Medical management}

The goal of treatment of physiologic jaundice is to prevent the level of serum bilirubin from rising. Two type of therapy can be used for infants with physiologic jaundice; phototherapy and exchange transfusion.

Phototherapy: the main form of therapy for infants with physiologic jaundice is phototherapy, the use of intense fluorescent light on the infant exposed skin it is belived that this light in the blue range acts to decompose bilirubin by the process of photo oxidation, phototherapy is effective in preventing or reducing an increase in bilirubin levels. The infant must be unclothed during treatment Figure 1. In order to prevent chilling, maintaining normal body temperature. The vital signs are taken at least every 4 hours to monitor the infant temperature.

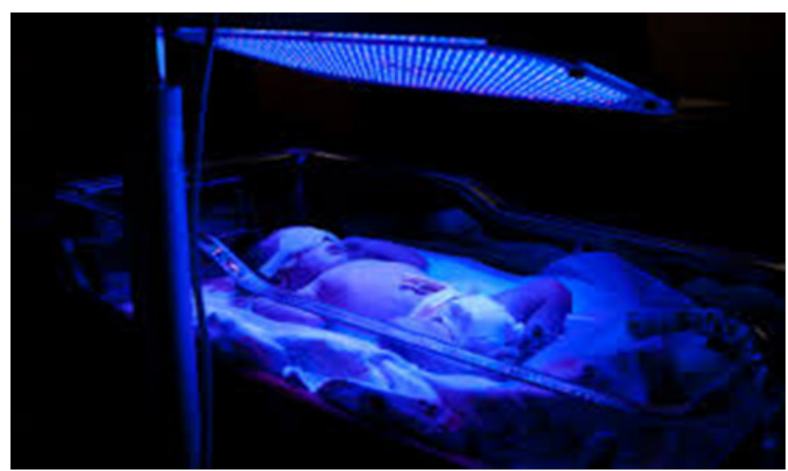

Figure I Child in phototherapy. 
Certain precaution must be taken to prevent injury to the infant during phototherapy; the infant's eyes must be shielded by an opaque mask. When infant is placed so that the testes are exposed to the light, a small folded diaper covers the area to prevent damage to these organs. A cap may be used to prevent heat loss from the head during phototherapy; bilirubin is checked at least daily, serum bilirubin levels usually fall 1 to $3 \mathrm{mg} /$ per $\mathrm{dl}$ after 8 to 12 hours of treatment. The phototherapy unit is turned off and the eye shields are removed for parenteral visiting and feeding. The treatment regimen using phototherapy may heighten parenteral anxiety during the infant first few days of life. When bonding usually occurs.

Phenobarbital therapy: Increased concentration of ligandin in liver cells. It induces hepatic microsomal enzymes and increases bilirubin conjugation and excretion. A loading dose of $10 \mathrm{mg} / \mathrm{kg}$ on day 1 and maintenance dose of $5-8 \mathrm{mg} / \mathrm{kg} /$ day for next 4 days is given. It takes 3-7 days to be effective. ${ }^{4}$

Exchange transfusion: Double volume exchange replacement $85 \%$ of circulating red blood cells and reduces bilirubin level by $50 \%$. Bilirubin can be removed from the blood most rapidly with exchange transfusion. It is used in full term infants with a hypebilirubinemia approaching $20 \mathrm{mg}$ per $\mathrm{dl}$ and in premature infants with bilirubin level approaching 10 to $15 \mathrm{mg} / \mathrm{dl}$. Exchange transfusion is rarely needed by infants having physiologic jaundice and is usually used for the treatment of hyperbilirubinemia due to blood group incompatibility (Figure 2)

\section{Exchange transfusion}

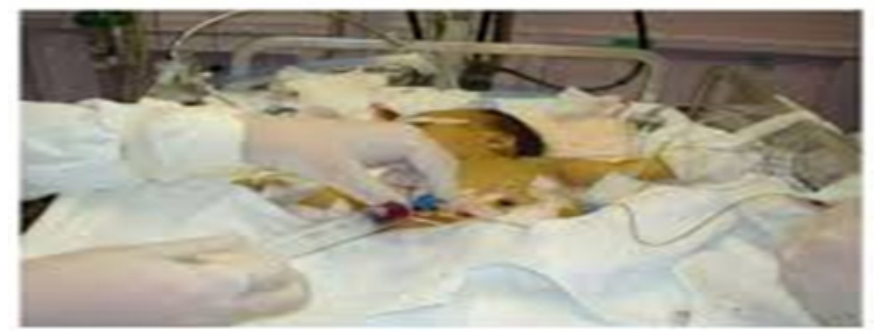

Figure 2 Exchange transfusion.

\section{Nursing management}

a. Providing proper care to baby and checking vital signs of the baby every hourly.

b. Child on phototherapy providing proper care and maintaining fluid level and hygiene of child.

c. Providing proper feeding and medication.

d. Maintaining aseptic technique, providing proper care.

e. Certain precautions must be taken to prevent injury to the infant during the use of phototherapy. Since this treatment cause damage to the photoreceptors in the retina, the infant eyes must be shielded by an opaque mask. Eyes are checked frequently for evidence of infection.

f. Providing psychological support to parents, explain about follow up care. ${ }^{5}$

\section{Prevention}

1. Phenobarbital is used prophylactically during pregnancy to prevent the occurrences of neonatal jaundice, especially when it is given for 2 weeks prior to the expected date of delivery.

2. Mother should eat less oily diet during pregnancy.

\section{Nursing diagnosis}

Fluid volume deficit related to phototherapy secondary to disease condition

Objective: child maintain normal fluid volume status

\section{Nursing intervention}

Assess fluid volume status of child by intake and output chart

i. Providing proper intravenous fluid to child

ii. Providing proper fluid to child

iii. Maintaining intake and output chart

\section{Altered skin integrity related to disease condition}

Objective: Child maintain normal skin integrity

\section{Nursing intervention}

a. Assess the skin integrity of child.

b. Providing proper care to child.

c. Changing position every hourly to prevent skin breakdown.

d. Apply powder to skin and back care to prevent skin integrity.

e. Applying emollient cream to child skin.

Altered body temperature related to infection secondary to disease condition

Objective: Child maintain normal body temperature

\section{Nursing intervention}

a) Assess the body temperature of child by thermometer.

b) Providing cold compress to child.

c) Providing tepid sponge to child.

d) Maintain proper ventilation in ward.

e) Providing antipyretic as per physician order.

Knowledge deficit of parents related to hospitalization, child condition, treatment

Objective: Parents gain knowledge about child condition

\section{Nursing intervention}

1. Assess the knowledge of parents by asking question.

2. Providing psychological support to parents.

3. Explain regarding hospital rules and regulation.

4. Explain about treatment of child to parents.

5. Providing diversional therapy to child and parents e.g.: books, music, TV.

\section{Acknowledgements}

None. 


\section{Conflict of interest}

The author declares no conflict of interest.

\section{References}

1. DC Duttas. A Textbook of Obstetrics. 7th ed. India: Springer; 2000.

2. Rajalakshmi Murugan. Comprehensive pediatric nursing's. India: Springer; 2004.
3. Dorothy R, Marlow. A textbook of pediatric. 8th ed. India: Springer; 2012.

4. Achar. A textbook of pediatrics. Newdelhi, India: Saunders Publications: 1992.

5. Guha DK. Neonatology Principle and practice. India: Jaypee Brothers Medical publication; 1997. 